\title{
Child Soldiers in Colombia: Five Views
}

\section{Niños soldados en Colombia: cinco visiones}

Recibido: junio 10 de 2010 | Revisado: octubre 15 de 2011 | Aceptado: marzo 19 de 2012

\author{
Jaime Alberto Carmona Parra* \\ Fundación Universitaria Luis Amigó de Medellín, \\ Colombia \\ FLORENTINO MORENO MARTín \\ Universidad Complutense de Madrid, España \\ JoHN FeLIPE TOBÓN HoYOS \\ Fundación Amigó, Madrid, España
}

SICI: 1657-9267(201209)11:3<755:CSICFV >2.0.TX;2-N

Para citar este artículo: Carmona, J. A. Moreno, F. \& Tobón, J.F. (2012). Child Soldiers in Colombia: Five Views. Universitas Psychologica, 11(3), 755-768.

* Decano de la Facultad de Psicología de la Fundación Universitaria Luis Amigó. Medellín Colombia.Email: jcarmona@funlam.edu.co

*** Docente Titular del Departamento de Psicología Social de la Universidad Complutense de Madrid. Email: fmoreno@psi.ucm.es

**** Coordinador de la Fundación Amigó. Madrid España.Email: jfelipetobon@gmail.com

\begin{abstract}
A B S T R A C T
This paper offers explanations of the meanings that push children to illegally armed groups in Colombia from the testimony of 21 demobilized young girls from the region of Antioquia (Colombia). The girls' answers are placed on a typology of explanations drawn from academic reports, and compared to three samples of attributions of students, teachers and policemen of their same region. The visions "idealizing" and "criminalizing" mobilization are practically marginal in all samples. The dominant vision among the girls is called "self-assertive". From the rest of the samples, as well as for the experts, the majority of the views are "victimizing".

Key words authors

Childhood, War, Colombia, Symbolic Interactionism.

Key words plus

Social and Community Psychology, Armed Conflict, Qualitative Research.
\end{abstract}

\section{RESUMEN}

Este trabajo enuncia algunos de los motivos que empujan a los menores a ingresar a los grupos armados ilegales en Colombia a partir de los testimonios de las 21 niñas desmovilizadas de la región de Antioquia (Colombia) en 2004. Se sitúan las respuestas de las niñas en una tipología de explicaciones extraída de informes académicos de expertos, y se compara con las atribuciones que hacen tres muestras de estudiantes, maestros y policías de la zona en estudio. Las visiones "idealizante” y “criminalizante” son prácticamente marginales en todas las muestras. La visión dominante entre las niñas es la denominada "autoafirmativa"; para el resto de las muestras, así como para los expertos, es mayoritaria la visión "victimizante".

Palabras clave autores

Niñez, guerra, Colombia, interaccionismo simbólico.

Palabras clave descriptores

Psicología social y comunitaria, conflicto armado, investigación cualitativa. 
On April 27 $7^{\text {th }}, 1979$ a nine-year-old boy by the name of Luis Alfonso Velasquez Flórez, who was an active member in the rebellion against Anastasio Somoza, was shot in the head by a soldier. The National Guard ran a military vehicle over him while he was still alive. A few months later, the Sandinista Movement came to power and to honor him they named parks, schools and children's associations after him. Not three years had gone by before Nicaragua was at war again. Now, the rebellion was led by the old Somocistas, in one of their armed incursions they attacked a hydroelectric dam, shooting a small group of poorly armed Sandinistas. A 15-year-old girl whose name was Brenda Rocha was gravely injured, but she managed to survive by playing dead, but lost her arm. When she was released from the hospital she lifted her stump before the enthusiastic crowd and said that she had lost an arm but was willing to give up her life for the revolution. A few days later, a poster with her childish face was displayed in public spaces around the country. The poster displayed the sentence "Brenda Rocha, the smile of Nicaragua."

Did Luis Alfonso and Brenda become part of the armed conflict after an informed decision moved by the principles of an ideology that defended the liberation of peoples? Were they manipulated, pushed to war, and taken advantage of in their immaturity and dependence by ideologist adults who flattered them or offered them money? Did they go over to the militia looking for the affective refuge that they lacked at home? Did they take up weapons in order to free their killing instincts? All these questions, except the first one, would have terribly offended any Sandinista in the turbulent 80 s; however, they can still use the interpretation to explain why these young people joined their enemies the "Contras". An empiric study carried out in 1989 in the war zones of Nicaragua and the refugee camps in southern Honduras where the Contras were located verified that both armed groups justified the incorporation of children as a voluntary process moved by the nobility of their cause. They would say for example "the child, despite his or her own nature, was able to interpret his or her world, identify his or her enemy and join the people's struggle" (Moreno,
1991, p 28). However, the same autonomy attributed to their young colleagues would disappear when applied to the affiliation of these children to the other side. In those cases, child militancy was attributed to coercion and deceit.

When trying to find the meanings behind children's involvement it is not appropriate to base one's assumptions on insights provided by those who share a home and a flag. Why not go directly to the source and ask them? This was the purpose of the research project mentioned in this article, carried out with all the young girls that demobilized from guerrilla and paramilitary groups in the region of Antioquia, Colombia (Carmona, 2009). However, it is precisely due to the fact that they are children that the testimonies they provided are regarded, in our time, with a deep sense of mistrust. When teenagers express that this was a willfulness act, we seek who or what specific circumstance coerced him or her to believe that they are free to carry a weapon. Thereby, the researcher faces the ontological dilemma of deciding whether to include the younger sectors that take up arms within the global logic provided by the exegetes of the armed groups to which they belong, or to apply the hermeneutic interpretation of the children's testimonies, thus interpreting their words as shadows proceeding from realities they cannot control. This is what science has applied in the last decades to explain the volunteering acts of child soldiers. The incorporation of boys into armed conflicts under 13 or 14 was naturally accepted until the 1980s. Even in European armies in which the military service was considered mandatory, 14 or 15 year-old boys were accepted under the epigraph of "volunteers". This situation of teenage participation in the army was so natural that on the November 20 $20^{\text {th }}, 1989$ UN Assembly in which the rights of children were declared, 18 was the age established to become an adult. However, 15 remained the age allowed for military recruitment. In the 1990s researchers started differentiating child soldiers from adults, usually with the noble purpose of establishing their recruitment as illegal or providing specialized treatment to any disorders caused by war, especially in refugee camps (Garbarino y Kostelny, 1997; 
Metraux, 1990; Moreno, 1991, 2000; Raulden and Melton, 1994).

In a short period of time, a transition has been made from highlighting the free will of teenagers who fight for noble ideals to questioning what strange reasons bring young people to want to risk their life by taking up a weapon. Very different organizations, ranging from the heroic children of Chapultepec (Mexico), the Battle of Children (Paraguay), Luis Alfonso and Brenda (Nicaragua) to Amnesty International, Human Rights Watch or Save the Children, Unicef Briefs (2005) or Graca Machel (1996) have denounced at international conventions war abuse against children. Studies regarding young adults' motivation to become part of armed groups highlight the struggle against injustice, ideological identification or sense of belonging to groups that fight for social causes (Flórez-Morris, 2007), or to those created on the basis of legitimation criteria for political violence (Sabucedo, Barreto, Borja-Orozco, López-López, Blanco, De la Corte \& Durán, 2006), all of which seem irrelevant to describe the causes that mobilize young people who are three or four years younger. During the last couple of years the studies that connect childhood or adolescence to armed activities have basically focused on the traumatic effects of such experience or on the description of the relation as a way to abuse or exploit (Hernández \& Romero, 2003). From a moral perspective it is a very big step, but from an ontological point of view this change in perspective requires an explanation. Have we, in the last decades, discovered that children lack the capacity to make relevant decisions, thereby making children's war acts not heroic but mechanical? Or, on the contrary, has the academic and popular sensibility changed towards war as to lead us to interpret children's joining war conflicts as a result of their immaturity?

In Colombia, most authors state that about $80 \%$ of the children who are part of illegally armed groups do it on a voluntary basis (Álvarez \& Aguirre, 2002; Coalition, 2003; Defensoría \& Unicef, 2006; HRW, 2003; Springer, 2007). However, the interpretations are divergent regarding the importance that each one of them grants to volunteering, arguing in favor of objective determinisms that push them to be part of a guerrilla or paramilitary group.

In order to approach a plausible description of the causes that bring the children to war we ought to start looking at the specific historical circumstances that the young boy or girl faces before deciding to take up a weapon. It is under this particular circumstance in which he or she sees a very limited set of explanations to justify his or her actions. The discourses that justify them are created by generations that at specific moments define the idea of war, childhood and political action (see Ortega, 1941, 1956). Even though the war phenomenon as a lethal confrontation between organized groups has several quasi-universal characteristics (Moreno, De la Corte \& Sabucedo, 2004), war and how it takes over the participant's psyche has a limited motivational choice of space and time. Thus, the purpose of our research, on which this article is based, focuses on the discourses that justify the participation of children in war and are therefore its backbone. When these discourses are present in a normal context going from ideas to beliefs it is not necessary to justify the incorporation of the armed conflict, in this case it becomes part of everyday life (see Berger \& Luckmann, 1966; Martín-Baró, 1989).

According to this premise, the purpose of this article is to specifically identify a time and place (Antioquia, at the beginning of the 21st century) the speeches or discourses that explain child involvement in illegally armed groups (I.A.G.) and to analyze how these discourses are taken up by the children who pick up a weapon and by the significant people in their environment (other children, teachers, police officers). If our initial premise is accurate-explanations clash between themselves, they have a historical characteristic and promote behavior- they are found in studies carried out by experts (who turn them into theory and legitimize it), in armed children that use weapons to bring meaning to their acts and important people that share their historical world of meanings. Even though we have stated that there is a set of limited and shared explanations, we understand that the roles that each group plays regarding the object of study influences the importance people give to each 
of the explanations. There is an important difference between the key players in the action that be explained from their interior and other important people trying to explain the behavior of others. At the same time, each group will lean towards one or another explanation according to their specific conditions (boys, girls, teachers, etc.).

In order to validate this idea, a content analysis of recent publications on child soldiers in Colombia has been carried out to identify the explanatory discourses on children's meaning regarding weapons. These categories have become a model for analyzing how important each one of them is for girl soldiers and, later, for comparing the importance that five different groups give to the same reasons. In every case, in order to be coherent with the purpose of this study and prevent answers from being biased, open questions were posed about the reasons young people have to get involved with the armed groups.

\section{Method}

There was a motivational typology based on the contemporaneous studies on the phenomenon in Colombia and from this analysis a structured matrix of five explanatory perspectives was extracted. 21 Colombian girls who demobilized from the armed conflict were interviewed and their responses analyzed using the matrix from the studies as a reference. Later, the analysis of responses given by students, teachers and police officers of the same region to an open question regarding the reasons why girls get involved in illegally armed groups was undertaken. Finally, the responses given by the demobilized girls were compared to those of the three groups from their community.

\section{Participants}

Four groups of people from the Antioquia region (Colombia) participated in this study. The main people were the 21 girls who demobilized in 2004 from illegally armed groups in this region, the total number of girls registered by the local government in the first semester of that year, which were part of a program of reintegration to civilian life carried out by the Colombian Institute of Family Welfare (ICBF) and the world migration organization WMO. The average age of the girls at the beginning of this study was 16 . Most of them had not finished their elementary education, they came from rural areas (only 15\% lived in municipality towns), their families were large and lived in conditions of extreme poverty, and they had been part of the illegally armed groups for nearly 2 years.

The second group was composed of young people from the region with similar characteristics to the girls who demobilized from illegally armed groups; however, they had no direct relation to such groups. There was a sample of 248 young people (194 girls and 154 boys), from $5^{\text {th }}$ to $7^{\text {th }}$ grade, between 10 and 15 years of age. The sample was chosen from nine different municipalities in Antioquia that reported high numbers of young people in illegally armed groups. These municipalities belong to the three regions in which 14 out of 21 girls joined the illegally armed groups. Three municipalities were from the region of Bajo Cauca: Caucasia, Cáceres and Tarazá; three from the northern region: Yarumal, Ituango and San Andres de Cuerquia; and three from the western region: San Carlos, San Luis, and San Rafael.

The second sample matches the socio-demographic profile with the ex-combatant girls (social strata, age, living in conflict areas, etc.). The differences between them were the current circumstances and the motivation they had to answer the questions posed by the researchers: the school girls assessed a phenomenon which they were not part of, whereas the demobilized girls offered in their answers the testimony of their experience in armed groups.

The third group was made up of teachers from different levels in the same municipalities previously mentioned. 138 female and 44 male teachers participated in this study. This important gender disproportion is a representation of the teaching staff of the region, mainly female teachers.

The fourth group was made up of police officers who work in the different rural areas of Antioquia with the highest rate of youth in illegally armed groups. Through the Departmental Commando of 
the Antioquia Police we were able to receive 182 responses from male officers that were undertaking educational activities in the city of Medellin.

All participants in this study were informed of the confidentiality conditions, they answered all questions freely and received no payment for their participation.

\section{Procedure}

A literature review was carried out from conventional academic sources for the elaboration of the structured matrix based on the explanations of reasons for joining illegally armed groups. However, for the effective creation of the set of explanations, the references were texts on the phenomenon of child soldiers, which can shed some light on their involvement in illegally armed groups referring to the Colombian conflict of the late $20^{\text {th }}$ and early $21^{\text {st }}$ century. Two characteristics were taken into account when selecting the literature: it had to be expository texts whether they were academic research reports or professional briefs on childhood and war in Colombia, and they should not be more than 10 years old. The selected literature was Álvarez and Aguirre (2002); Bello and Ruiz (2002); Coalición contra la vinculación (Coalition against involvement) (2003); Defensoría del Pueblo (2006); González Reyes (2004); Hernández (2001); Human Rights Watch (2003) [from now on HRW]; Informe Nacional de Desarrollo Humano (2003) [from now on INDH]; Instituto Colombiano de Bienestar Familiar (2004) [from now on ICBF]; Páez (2001); Springer (2007) and Unicef (2005). The documentary analysis was carried out in two phases, taking as reference the methodological premises of symbolic interactionism. In the initial or exploratory phase, there was a selection of contents that make reference to the reasons for child war involvement. In the second, or inspection phase, the analysis of the chosen texts for the purpose of "unearthing generic relations, [...] sharpening the connotative reference of his concepts, and [...] formulating theoretical propositions" (Blumer, 1969, p. 48). An explanatory matrix was elaborated in this categorization phase with the explanations that defined reasons for child involvement in the war, under criteria that could be considered mutually excluding in conceptual terms, but with close argumentative relations nonetheless. Based on that matrix, the arguments were placed into five major categories around the concepts of victimization, passion-pathology, crime, ideology and self-assertion. These five groups included subcategories that became their reference for analyzing the responses from the four sample groups, which improved the original matrix with some complementary subcategories.

In order to find the reasons that the 21 girls expressed to get involved in illegally armed groups, some in-depth interviews were carried out during the three months that the research group was at the institution in which the girls began their reintegration process to civilian life. The interviews were open and recorded (audio) for an unlimited time. Once they were transcribed, the analysis process began based on the texts by Bardin (1977) and Krippenndorff (2002): first, all paragraphs that made reference to possible reasons of why they got involved in the illegally armed groups were chosen in order to pre-classify them in one or another category. Since the testimonies came from open conversations, the selected paragraphs did not have the characteristics of an answer to a direct question regarding their motives. Sometimes the girls provided answers with direct explicit arguments that fell right into the categories that were established in the analysis phase undertaken on the basis of texts from experts. On some other occasions, the reasons came up in a story (for example the story of how she fell in love with a man from a guerrilla group). For the final classification in a category or in a specific case for the creation of a new one, the sentence or groups of sentences were determined based on the motivational purpose inferred from the semantic unit. Therefore, a comment about weapons could end up in the "ludic subcategory" if there was an emphasis on weapons as exotic toys or aesthetic pleasure, that is, weapons as ornaments; in the "desire of power subcategory" if they implied the idea of improving their status; or in the "criminal desire" one if it were part of a story in 
which a weapon had a role of cruelty. In this phase there was a differentiation of the reasons expressed by the girls, followed by a categorization process based on the matrix that displayed the results of the texts' analysis, after which they were placed into the 14 subcategories that became part of the five perspectives.

The responses from the sample groups of students, teachers and police officers were based on the analysis of an open question used at the beginning of the questionnaire that was answered in schools by teachers and students, and at the Antioquia Police Command Center. For all groups, a member of the research group picked up the questionnaires in order to guarantee the anonymity of the participants. The question posed was: what reason do you think young girls under 18 have to join paramilitary or guerrilla groups in your region? Even though the question was posed using the singular form of the verb, most people provided two or more arguments. The groups were divided into male and female participants in order to analyze the information by gender. The answers were classified in the 14 subcategories drawn from the analysis of academic texts and the answers provided by the girls who demobilized from illegally armed groups: 389 female students; 294 male students; 277 female teachers; 88 male teachers and 364 police officers. The analysis of these responses was carried out under the same procedure applied to those provided by the girls.

\section{Results}

In order to describe how the motives expressed by the girls regarding why they got involved in illegally armed groups and how they are similar to those expressed by people in the same geographical region and cultural environment, we will first describe the fifteen categories classified in five major perspectives on the phenomenon based on Colombian academic texts and ideas expressed by groups from the same regions as those of the girls who participated in this research project. We will present the frequency rate that describes the importance assigned by each group to each category in terms of all answers. Finally, we show the most important coincidences and divergences between the level of importance given to each vision by each group taking as a reference the girls' testimonies.

\section{Five perspectives}

The presentation of the five explanatory perspectives and the categories that compose them was carried out following a procedure that takes as a reference the level of autonomy that a young person has in the decision of becoming part of an armed group. It goes from a deterministic explanation in which the capacity to decide is basically zero (deceit, extreme poverty, etc.) to an indeterministic perspective in which children are given full decision capacity.

\section{Victimizing perspective}

The young person is forced to go to war either by deceit or threat, or serious biographical circumstances such as poverty or abuse that push him or her to the training camps. Thus the young person's decision capacity is limited, under the circumstances he or she can, therefore, be considered a victim. This perspective considers two clearly differentiated forms of victimizing, on the one hand, there is the coercion through threat or deceit and, on the other, there is the militia as a "refuge" or way to survive.

Regarding the incidence of coercion and deceit, researchers of this phenomenon in Colombia agree that forced involvement of children in illegally armed groups is actually quite low, ranging somewhere between $10 \%$ and $25 \%$ of the cases (Álvarez and Aguirre 2002; Carmona, 2009; Coalición, 2003; Defensoría, 2006; Human Rights Watch, 2003). Some testimonies of the people that were interviewed were: "because they take them by force, they want to rape them and kill them" (girl student); "because they lie to the girls, so they can take them away" (boy student); "sometimes they force the girls, and they goin order to avoid the death of a family member" (female teacher); "because they have been deceived with promises" (male teacher); "because the commanders of these groups want to have women, not 
so much for the combat but for their personal satisfaction and love affairs" (police officer).

In specialized bibliography most victimizing explanations are based on contexts that in one way or the other "cast" them out from their problematic family and community environment, placing them at the hands of some groups that become a refuge for them? (Aguirre, 2002; Coalition, 2003; INDH, 2003). The two most common elements are poverty (González, 2004) and family abuse (Coalition, 2003). Some authors group the contextual elements into some sort of institutionalization that normalizes the involvement of young people in the armed groups, as part of a socialization process, in places where they are quite important (Álvarez and Aguirre, 2002). Let us analyze some of these testimonies as expressed by students and police officers: "Because their parents beat them and they rather get involved in armed groups than be punished by their parents" (boy student); "because they were born and raised in guerilla and paramilitary areas" (police officer).

\section{Passional-pathologizing perspective}

The young person would get involved in the war because he or she is pushed towards it by an emotional relationship that creates a bond with those that play a lead role in it (like falling in love with a soldier, family ties), or as a way to express the psychological phenomena of the age (teenage crisis) or to disruptions directly or indirectly related to war (grief, vengeance, pathology, etc.).

The passional-pathologizing perspective, likewise, has a determinist inspiration, but instead of emphasizing on the explanation of external forces it moves towards internal factors that are beyond the will and reasoning of girls and boys. The forces that lead these young people to become part of the war are not the social or family structures, but love affairs and passions (Álvarez y Aguirre, 2002; INDH, 2003); family ties (INDH, 2003; HRW, 2003; Páez, 2001); or the desire for revenge (Coalición, 2003; Hernández, 2001) which would create an unstoppable impulse to join a group. Another reason that may be quite important for young people to join these groups are the ups and downs related to adolescence (Defensoría, 2006, p.
19) and those emotional disturbances or psychological pathologies associated or not to trauma (Bello \& Ruiz, 2002). Some scholars with a psychoanalytic inspiration could also propose the hypothesis that an unconscious trauma could also be determinant, in the sense that it could bring a human being to the active reproduction of violence suffered as a passive victim (Zapata, 2007). Some expressions of the people that were interviewed are somewhere along this line: "because of sadness, because she thought no one loved her, or she wanted to die because she was ugly" (girl, student); "some girls fall in love with a combatant, that is, they do it because of sentimental attraction" (boy, student). "Because they want to avenge the death of a family member" (female teacher); "because of a passionate relation to the subversive group members" (police officer).

\section{Criminalizing perspective}

The young person that gets involved in the armed conflict, under this perspective, would not be different to a juvenile delinquent that opts for illegality to enjoy privileges or as a way of expressing their criminal and destructive tendencies.

The criminalizing interpretation of young people in the war activity distances itself from social determinism and locates the source of involvement in the teenage will that finds in illegal groups an appropriate context to satisfy selfish and cruel appetites. In the academic field, this perspective is marginal and it is usually introduced in an indirect way (Díaz, 2002). However, there are some very committed defenders in the judicial field: "The rejection of to penal responsibility of teenagers is a rejection to the tout court (...) the adolescent condition cannot be the way to turn Latin America into a corso patent (García, 2003)".

In the Colombian legislative practice this perspective has had the most influence, as can be seen in the section that deals with the system of penal responsibility for teenagers in article 139 of the Childhood and Adolescence Code, Law 1098 from November 8, 2006, ratified by the Congress of the Republic of Colombia, which lowers to 14 the age to criminalize young people who get involved in illegally armed groups. 
The people that were interviewed hardly express it as a valid argument, here are some: "because they are evil and enjoy violence, they like to see blood on the floor and dead people" (girl, student); "they want to have a gun to kill. Because they like to kill others and other people, and grab a gun, and kill each other" (boy, student); "They like to kill people" (police officer).

\section{Idealizing perspective}

The reasons that bring a young person to take up weapons are related to the ideas of the group that they join. They see themselves as part of the ideology or cause of the group and they do not hesitate to place their lives at risk.

One of the important elements of our study is that this interpretative approach for getting involved in an armed group is basically non-existent in the Colombian bibliography on the phenomenon, but it can be found in studies referenced in other moments of history like the Central American wars of the 1980s or even the Colombian conflict of that time. The research project Mujeres no Contadas (Untold women) that analyzes the experience of excombatant women of different Colombian guerilla groups, provides a very worthy testimony of this perspective: "even for those women that expressed having felt more attracted by the military perspective than the political one, or for those who had a less political education, their experience in the participation in rebellious groups had a political sense: the transformation of social conditions of inequality and injustice" (Londoño $\&$ Nieto, 2006, p. 55). There is a similar response given by Salvadorian guerrilla of the 1980s regarding the issue of children in the guerrilla:

it is very simple, because THIS IS what they want to do. Children want war to be over as soon as possible and they want soldiers to disappear from their lives. They know that their cooperation is quite important to make this a reality, because they see results in their participation and that motivates them to continue living and cooperating, even when they know they are risking their lives. It is something that they have learned all by themselves due to the hard reality they have faced for so long (Moreno, 1991, p. 26).
The well-known Graça Machel brief for the United Nations places it as one of the possible explanations for the not-forced incorporations of children to armed groups in the world:

even though, it is important to observe that children can also feel part of social causes, religious motives, free determination or national liberation and fight for these causes. Just as it took place in South Africa or in occupied territories, children can become part of a struggle in order to strive for political liberty (Machel, 1996).

Such idealist motivation is analyzed in this fashion by some of the people who were interviewed: "in order for the town or country to be a better place with their help" (girl, student); "they disagree with government laws because they find them unfair" (student, boy); "they don't want to be part of the country's injustice" (female teacher).

\section{Self-assertive perspective}

In this perspective, young people become part of the war as an option of life, which is in itself attractive, which suits their likes, and contributes to making some of their adolescent desires and expectations a reality.

Unlike the classic perspective, which describes the young volunteers as idealists who go to war with an ideological purpose but actually find an intense military life that marks them, this perspective emphasizes that young people join these groups looking for that very same intensity and life style of the group. Instead of the circumstances that offer them immediate welfare (study, marriage, migration, work...), they choose the way of the military life, an attractive path in itself. Most contemporary studies retrieve this perspective directly extracted from children's testimonies (Álvarez and Aguirre, 2002; Coalición, 2005; Defensoría, 2006; González \& Reyes, 2004; Páez, 2001). Some researchers openly highlight such contradictions among their own deterministic explanations (deceit, family abuse, poverty, disturbances) over this self-affirmation perspective. This perspective could be regarded as frivolous 
because it basically expresses ludic aspects related to the desire for adventure; the power to act with a certain degree of freedom; adolescent fun such as parties; even the mere aesthetic pleasure that comes from picturing themselves in uniforms and holding sophisticated mechanical toys (Álvarez \& Aguirre, 2002; Coalición, 2005; Defensoría, 2006).
Some testimonies expressed by students, teachers and police officers immediately stated: "Because they feel better there and they get to do whatever they want" (student, girl); "because they thought they would look pretty in uniforms" (student, boy); "they do it as a life choice" (female teacher); "it is an option, something captures their attention" (male teacher); "they like it and since they cannot become part of State Institutions..." (police officer).

TABLE 1

\begin{tabular}{|c|c|c|c|c|c|c|}
\hline Percentages of answers on motives for affiliation & 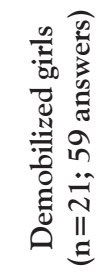 & 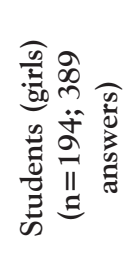 & 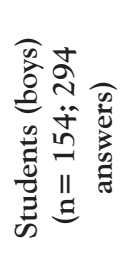 & 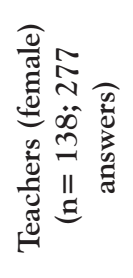 & 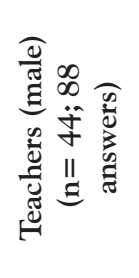 & 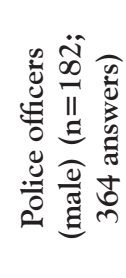 \\
\hline \multicolumn{7}{|l|}{ 1. Victimizing } \\
\hline Forced or deceived affiliation & $5.1 \%$ & $20.3 \%$ & $14.3 \%$ & $14.4 \%$ & $11.4 \%$ & $28.6 \%$ \\
\hline Poverty & $0.0 \%$ & $19.8 \%$ & $24.5 \%$ & $40.4 \%$ & $30.7 \%$ & $39.6 \%$ \\
\hline Domestic violence & $18.6 \%$ & $26.2 \%$ & $19.4 \%$ & $22.0 \%$ & $25.0 \%$ & $15.4 \%$ \\
\hline Violence institutionalization & $0.0 \%$ & $1.0 \%$ & $1.0 \%$ & $0.0 \%$ & $1.1 \%$ & $1.4 \%$ \\
\hline Subtotal & $23.7 \%$ & $67.4 \%$ & $59.2 \%$ & $76.9 \%$ & $68.2 \%$ & $84.9 \%$ \\
\hline \multicolumn{7}{|l|}{ 2. Passionate pathologizing } \\
\hline Falling in love & $10.2 \%$ & $5.9 \%$ & $4.4 \%$ & $7.6 \%$ & $9.1 \%$ & $2.2 \%$ \\
\hline Filial love & $10.2 \%$ & $0.5 \%$ & $1.0 \%$ & $0.0 \%$ & $0.0 \%$ & $0.8 \%$ \\
\hline Grief/ revenge & $5.1 \%$ & $9.0 \%$ & $11.9 \%$ & $5.1 \%$ & $6.8 \%$ & $4.1 \%$ \\
\hline Puberty crisis & $0.0 \%$ & $0.8 \%$ & $2.0 \%$ & $2.9 \%$ & $1.1 \%$ & $0.0 \%$ \\
\hline Pathological factors & $3.4 \%$ & $3.6 \%$ & $4.4 \%$ & $1.1 \%$ & $0.0 \%$ & $0.3 \%$ \\
\hline Subtotal & $28.8 \%$ & $19.8 \%$ & $23.4 \%$ & $16.6 \%$ & $17.0 \%$ & $7.4 \%$ \\
\hline \multicolumn{7}{|l|}{ 3. Criminalizing } \\
\hline Criminal wishes & $0.0 \%$ & $8.0 \%$ & $8.5 \%$ & $0.0 \%$ & $0.0 \%$ & $0.8 \%$ \\
\hline Subtotal & $0.0 \%$ & $8.0 \%$ & $8.5 \%$ & $0.0 \%$ & $0.0 \%$ & $0.8 \%$ \\
\hline \multicolumn{7}{|l|}{ 4. Idealizing } \\
\hline Ideological reasons & $1.7 \%$ & $0.5 \%$ & $1.7 \%$ & $1.1 \%$ & $0.0 \%$ & $0.0 \%$ \\
\hline Subtotal & $1.7 \%$ & $0.5 \%$ & $1.7 \%$ & $1.1 \%$ & $0.0 \%$ & $0.0 \%$ \\
\hline \multicolumn{7}{|l|}{ 5. Self-assertive } \\
\hline Adventure & $23.7 \%$ & $2.1 \%$ & $0.7 \%$ & $2.5 \%$ & $6.8 \%$ & $1.9 \%$ \\
\hline Ludic motivation & $13.6 \%$ & $0.3 \%$ & $1.7 \%$ & $0.0 \%$ & $2.3 \%$ & $0.5 \%$ \\
\hline Aesthetic pleasure & $8.5 \%$ & $0.5 \%$ & $0.7 \%$ & $0.7 \%$ & $1.1 \%$ & $0.0 \%$ \\
\hline Desire for power & $0.0 \%$ & $1.5 \%$ & $3.7 \%$ & $2.2 \%$ & $4.5 \%$ & $4.4 \%$ \\
\hline Subtotal & $45.8 \%$ & $4.4 \%$ & $6.8 \%$ & $5.4 \%$ & $14.8 \%$ & $6.9 \%$ \\
\hline Total & $100 \%$ & $100 \%$ & $100 \%$ & $100 \%$ & $100 \%$ & $100 \%$ \\
\hline
\end{tabular}

Fuente: elaboración propia 


\section{Coincidences and differences between the demobilized girls and other community members}

There is great agreement on the idea of considering the idealizing and criminalizing perspectives as marginal. The consideration that ideological factors are irrelevant for girls and for others is basically unanimous. There is also agreement on the little importance given to criminal impulses or delinquent purpose as the cause for joining. It is important to point out that this perspective is considered meaningful by about $8 \%$ of the students, for the rest of the population it holds no importance.

There is also a very similar distribution of the answers related to forced involvement through deceit or threat. However, it seems like the distance is between $5.1 \%$ of the demobilized girls and $28.6 \%$ of the police officers. It is necessary to bear in mind that the only three answers came from the former soldier girls, coincidentally those girls who claim to have been forcefully recruited. If the analysis of the answers were to be carried out not with all the responses but based on the 21 girls of the study, forced recruitment would be $15.3 \%$, which would place it in the narrow span of answers from the rest of the people.

The main difference between the demobilized girls and the rest of the population is the importance girls give to self-affirmation related reasons (adventure, ludic motivation, aesthetic pleasure, fun, etc.) as opposed to others. The percentage of their answers is a total of $45.8 \%$, four times what others expressed, a total of $14.8 \%$ of male teachers. Most of the girl's testimonies were along this line (names have been changed): "what I liked about the guerilla is the idea of living among so many people and living like in the mountains, and walk, and walk, and walk" (Silvia); "I could see that everything was good there, because when they came to a town it was so easy and there were many good things, they also seemed to have a good time, they very often had parties" (Verónica). "The thing is we saw how pretty the weapons were; because we never suffered in my house, we were never abused or anything but we looked at the pretty weapons, when we saw the women wearing the camouflaged uniform and we thought that was very good" (Marcela).

We find that there is a great difference between the importance the demobilized girls give to poverty as a spur for military life, and the importance the rest of the people give to it. None of the 21 ex-combatant girls even mentioned this factor. Sometimes this argument was even refuted explicitly: "We never thought of getting involved for money, but we would sometimes talk and we would even tell mother that we wanted to be part of it, not to go just because of that, not to join just because of that. Because the moment I made up my mind to go to the armed group it wasn't just because of that, but because I was so unhappy at home" (Lucía).

Another important difference between the demobilized girls and the rest of the people was the importance given to love affairs and passion as the main cause. If we add up the romantic love and family ties, we encounter that they represent more than $20 \%$ of all the explanations. Some former soldier girls expressed it like this: "I made up my mind to go to group because of him, I mean, I was so in love with him.... If someone else had asked me to join the group, I wouldn't have gone. I don't think so, because that was my reason to go, that he was there" (Pilar); "I cried when he left, that is why I went to the guerrilla, and out of spite I said: I'm going too" (Isabel).

If we analyze the information, in terms of the groups that they represent, dividing them into students, teachers and police officers, not differentiating gender, we encounter, as expected, that the students (boys and girls) gave answers that were more similar to those of the demobilized girls than those of the adults. Thus, the students find the victimizing value $(63.8 \%)$ less frequent than adults do; teachers assigned it $74.8 \%$ and police officers $84.9 \%$. As complementary information, they came closer to the passional-pathologizing explanations given by solider girls with $21.52 \%$ of answers related to the passions before an $11.6 \%$ given by the teachers and $7.4 \%$ by the police officers. As to the importance given to the self-assertive and ludic-expectation explanations, there is very little difference in all the groups of the community: students $5.4 \%$, teachers $(7.7 \%)$ and police officers (6.9\%). However, it 
is the major difference between these groups and the demobilized girls gave this perspective a value of $45.8 \%$.

\section{Discussion}

The purpose of this article has been to identify the discourses that explain child involvement in illegally armed groups and prove how such discourses are assimilated by the children who take up arms and by the significant people in their environment. The results indicate that the girls who decided to get involved in armed groups interpret the reasons for their affiliation in a significantly different way. Social scientists with their concepts based on empirical research, school and police officers, authority figures as well as school children, all of them make a relevant part of what George H. Mead (1953) labeled as the "generalized Other", the normative referent for the girls who were part of the study, a framework they have as reference, but one they do not completely follow in their explanations.

In our approach to the motives that push children into armed conflicts, five perspectives have been identified to understand the phenomenon. All of them have a significant place in scientific literature. When contrasting such explanations with the direct responses of those who have lived in conflict areas during the first years of the 21st century, we have been able to establish that the idealizing and criminalizing perspectives are almost irrelevant to the demobilized girls, their fellow students, teachers and police officers, who do not believe that they have joined the groups because of ideological motives nor because of child criminal impulses. It was also established that the former combatant girls hold their decision autonomy as one of the most important motives for their involvement in the group. Their decision is based on criteria related to their adventure desires, ludic expectations and the fulfillment of their affections; however, they also take other factors, like family violence, as motives that interact with each other. People, who from a long distance context, try to find an explanation as to why these children make a move towards armed groups have a tendency to focus on social determinisms such as poverty and coactive forms for involvement through threats and deceit.

The greater the difference in age and condition between members of these groups and demobilized girls, the more prone they are to magnify the objective determinisms and to disregard passions as a motive for military involvement. The role played by students, teachers and police officers in the social world conditions the explanations of this phenomenon. Just as researchers have a hard time believing that children say they took up the arms for ludic reasons; teachers find it difficult to see them with labels like criminal desires or pathologies. The relationship between teacher and student has always been associated to trust and affection towards the pupil.

The fact that police officers basically do not give explanations different to poverty, domestic violence o coercion, except for the small percentages attributed to revenge or desire for power, can be interpreted in this way: police officers almost totally deny the possibility that young children may actually find something positive in the illegally armed groups. It is a way of delegitimizing the purpose of those groups that oppose their work as keepers of public order, doing so proves important for legal and psychosocial reasons. It makes it easier to proscribe others, in a violent political context it is appropriate for "excluding adversaries of human groups that act within the acceptable limits for society" (Barreto \& Borja in Borja-Orozco et al., 2008). On the other hand, the attribution to external factors suppose in our opinion a rupture of the cinematographic stereotype that constantly shows police officers attribute the violence and murderous desires to children.

We would like to highlight in our study the effect these perspectives have in developing identity when they are rooted in large groups of people with decision-making power. If the child soldier is seen as a product of exclusion and social injustices (victimizing perspective) the logical answer is to protect him or her and, consequently, the intervention projects ought to integrate these children into protection programs. In these cases, the demobilized child is considered someone similar to a homeless 
child or someone who has been abandoned. If the child solider is considered as a sort of mentally alienated person, incapable of making his or her decisions in a normal way (perspective passionalpathologizing), the congruent proposal ought to be that of treatment, such as those implemented by some institutions which develop projects with demobilized children from illegally armed groups under the model of the therapeutic-community therapy used for drug users. This category would be made up by programs that try a "psychic reconstruction of the child" implemented in Ruanda, Burundi and Congo in 1997 (Desmarais, 2002, p. 69). If the image is that of a juvenile delinquent (criminalizing perspective) the logical perspective would be to isolate him or her in a reclusion center, in order to protect the community from the danger this child represents. If the vision that dominates is the one in which the child joins these groups on the grounds of convictions (idealizing perspective) the strategy could be, as has been the case for decades, to place him or her as war propaganda, or to persuade the child in order to change his or her ideological orientation. Finally, if the perspective is that of an active social agent that sees him or herself as responsible for his or her own actions, and the process of involvement displays the self-assertive perspective, the response of intervention ought to focus on a strategy that guarantees their rights and is oriented to allow them to take responsibility for their own process of returning to civilian life. This should be accomplished without losing the perspective on the particularity of child or teenage meanings on which their world and decision-making are based.

The professionals that work in reinsertion projects with child soldiers in Colombia establish the influence of identity of the social processes considered as victimizing and deterministic perspective (Moreno, 2000). One of the professionals who work in these projects clearly expresses it: "this program is based on a different national and international perspective. Many people do not believe that individuals are responsible for their own process, but we think of them as children with guaranteed rights and with rights to everything. However, the conception of duty and responsibility is still very poor. In this perspective, it is extremely difficult to work and play with them because sometimes it's like they deserve everything but without doing the least effort to get what that they want" (Pinzón, 2006).

The results of this study could contribute to reflect on the possible paradoxical effect of the well-intentioned perspectives in the process of reinsertion to civilian life. The victimizing and pathologizing perspectives on child soldiers that have a fundamental deterministic inspiration can bring de-responsibilization identity effects on the young former soldier and can be a fundamental limitation for the construction of prevention and intervention actions. For, once the phenomenon theory that states children's capacity to see themselves and act as responsible is left aside, they are deprived of this most precious element in order to successfully carry out their process of reintegration to civilian life. The criminalizing and idealizing perspectives, which have the contrary effect of producing over-responsibility and generating guilty-identity effects, have the undesirable effect of tautologically explaining a psycho-social behavior as an effect of the actor's essence and being an excuse for repressive proposals. Likewise, the idea of belonging to a minority and stereotyped group can open the way to promote a group identity and have a reaffirming effect over such marginality, as suggested by the social identity theory (Tajfel \& Turner, 1979).

A responsibilizing perspective based on recognizing the former combatant girl's capacity of agency (self-assertive perspective) (Carmona, Moreno, \& Tobón, 2012) does not ignore the influence of internal and external factors on the phenomenon, it even includes responsibility as a guarantee of personal independence. Furthermore, such perspective ought to be assumed by adequately contextualizing the ludic expectations as part of the evolution those girls undergoing. We must not leave aside the fact that our own interpretative context is historically characterized and, therefore, its value should not be based on how close it comes to reality but, rather, on the possibility to change it. 


\section{References}

Aguirre, J. (2002). Niñez y Juventud en el conflicto armado interno en Colombia. In M. Bello \& S. Ruiz. (Eds.), Conflicto armado, niñez y Juventud, una perspectiva psicosocial (pp. 15-65). Bogota: Universidad Nacional de Colombia.

Álvarez-Correa, M. \& Aguirre, J. (2002). Guerreros sin sombra. Niños, niñas y jóvenes vinculados al conflicto armado. Bogota: Procuraduría General de la Nación \& ICBF.

Bardin, L. (1977). El análisis de contenido. Madrid: Akal. Bello, M. \& Ruiz, S. (Eds.) (2002). Conflicto armado, ninez y juventud: Una perspectiva psicosocial. Bogota: Universidad Nacional de Colombia.

Berger, P. Luckmann, T. (1966). The Social Construction of Reality. New York: Doubleday.

Blumer, H. (1982). El interaccionismo simbólico, perspectiva y método. Barcelona: Hora.

Borja-Orozco, H., Barreto, I., Sabucedo, J.M \& LópezLópez, W. (2008). Construcción del discurso deslegitimador del adversario: gobierno y paramilitarismo en Colombia. Universitas Psychologica, 7(2), $571-583$.

Carmona, J. (2009). La carrera de las niñas soldado en Colombia: un estudio desde el punto de vista del agente. Madrid: Universidad Complutense de Madrid, Servicio de Publicaciones. Col: Tesis Doctorales.

Carmona, J., Moreno, F. \& Tobón, J. (2012) La carrera de las niñas en los grupos guerrilleros y paramilitares de Colombia: un estudio desde el punto de vista del agente. Medellin: Fondo Editorial Funlam.

Coalición Contra la Vinculación de Niños, Niñas y Jóvenes al Conflicto Armado en Colombia (2003). Contexto: la situación de niños, niñas y jóvenes en el marco del conflicto armado en Medellín. Medellin: Coalición.

Defensoría del Pueblo \& Unicef (2006). Caracterización de los niños, niñas y adolescentes desvinculados de los grupos armados ilegales: Inserción social y productiva desde un enfoque de derechos humanos. Bogota: Defensoría del Pueblo \& Unicef.

Desmarais, M. M. (2000). La reconstrucción de las personas. In: J.M. Fernández Martos \& F. Miralles Sangro (Eds.), Sin lugar para ser humano: interven- ción psicológica en crisis humanitarias (pp. 69-84). Madrid: Universidad Pontificia de Comillas.

Díaz, C. (2002). Jóvenes Guerreros: elecciones, pasajes y pasos. In M. Bello \& S. Ruiz (Eds.), Conflicto armado, niñez y juventud, una perspectiva psicosocial (pp. 77-91). Bogota: Universidad Nacional de Colombia.

Flórez-Morris, M. (2007). Joining guerilla groups in Colombia: Individual motivations and processes for entering a violent organization. Studies in Conflict Eु Terrorism, 30(7), 615-634.

Garbarino, J. \& Kostelny, K. (1997). What children can tell us about living in a war zone. In J. D. Osofsky (Ed.), Children in a violent society. (pp. 32-41). New York, NY, US: Guilford Press.

García, E. (2003). Niñez y conflicto armado. Bogota: Universidad de los Andes.

González Reyes, F. (2004). Iniciativa para prevenir la vinculación de la niñez al conflicto armado (PNUD, ICBF, Defensoría, Unicef, OIT, OIM). Retrieved from http://indh.pnud.org.co/articulo

Hernández, E. (2001). Los niños y las niñas frente al conflicto armado y alternativas de futuro. Reflexión Política, 3 (6), 1-11.

Hernández, P. \& Romero, A. (2003). Adolescent girls in Colombia's guerrilla: An exploration into gender and trauma dynamics. Journal of Prevention $\mathcal{E} \mathrm{In}$ tervention in the Community, 26(1), 21-38.

Human Rights Watch. (2003). Aprenderás a no llorar: niños combatientes en Colombia. Retrieved from http://www.hrw.org/legacy/spanish/informes/2003/ colombia_ninos.html

Informe Nacional de Desarrollo Humano (INDH) 2003 (2003). El conflicto, callejón con salida. Bogota: Programa de las Naciones Unidas para el Desarrollo.

Instituto Colombiano de Bienestar Familiar -ICBF(2004). Tercer informe de Colombia al Comité de los Derechos del Niño 1998-2003. Bogota: ICBF.

Krippendorff, K. (2002). Metodología de análisis de contenido: teoría y práctica. Barcelona: Paidós.

Londoño, L. \& Nieto, Y. (2006). Mujeres No Contadas: Proceso de desmovilización y retorno a la vida civil de mujeres excombatientes en Colombia 1990-2003. Medellin: Carreta Social.

Machel, G. (1996). Impact of armed conflicts on children (Report \# A/51/306). New York: United Nations. 
Retrieved from http://www.unicef.org/graca/a51306_en.pdf

Martín-Baró, I. (1989). La institucionalización de la guerra. Revista de Psicología de El Salvador 8 (33), 223-245.

Mead, G. H. (1953). Espíritu, persona y sociedad. Buenos Aires: Paidós.

Metraux, J. C. (1990). El niño, la familia y la Comunidad. Manual de atención sico-social para promotores. Managua: Editorial Ciencias Sociales.

Moreno Martín, F. (1991). Infancia y Guerra en Centroamérica. San Jose: FLASCO.

Moreno Martín, F. (2000). Criterios para la intervención psicológica con menores víctimas de la guerra. En J.M. Fernández Martos y F. Miralles Sangro (Eds.), Sin lugar para ser humano: intervención psicológica en crisis humanitarias (pp. 115-132). Madrid: Universidad Pontificia de Comillas.

Moreno Martín, F., De la Corte, L. \& Sabucedo, J. M. (2004). Psicosociología de la guerra: causas y efectos, In L. De la Corte, A. Blanco \& J. M. Sabucedo (Eds.). Psicología y derechos humanos (pp. 145-187). Barcelona: Icaria.

Ortega y Gasset, J. (1941). Historia como sistema. Madrid: Revista de Occidente.

Ortega y Gasset, J. (1956). En torno a Galileo: esquema de la crisis. Madrid: Revista de Occidente.

Páez, E. (2001). Las niñas en el Conflicto Armado en Colombia: Un diagnóstico. Bogota: Terres des hommes.

Pinzón, P. (2006). [Interview carried out in July, at Centro de Atención Especializada "Libertad y Esperanza”] (Tape recording № 01 - 02). Medellin.
Raundalen, M. \& Melton, G. B. (1994). Children in war and its aftermath: Mental health issues in the development of international law. Behavioral Sciences $\mathcal{E}$ the Law. Special Issue: Children and Violence, 12 (1), 21-34.

Sabucedo, J., Barreto, I., Borja-Orozco, H., López-López, W., Blanco, A., De la Corte, L. \& Durán, M. (2006). Legitimación de la violencia y contexto: análisis textual del discurso de las FARC-EP. Estudios de Psicología, 27(3), 279-291.

Springer, N. (2007, August). Avances de resultados de la investigación de la Organización Internacional de Migraciones: "Prisioneros combatientes. Del uso de niños, niñas y adolescentes para los propósitos del conflicto armado". Paper session presented at the Forum "La guerra no es nuestro juego, déjennos crecer en paz", organized by the IOM, Unicef, OCHA, Procuraduría \& Gobernación de Antioquia. August 30th, 2007, Medellin.

Tajfel, H. \& Turner, J. C. (1979). An Integrative Theory of Intergroup Conflict. In W. G. Austin y S. Worchel (Eds.), The social psychology of intergroup relations (pp. 33-47). Monterrey, CA: Brooks-Cole. Unicef (2005). Estado Mundial de la Infancia 2005. Retrieved from http://www.unicef.cl/centrodoc/ emundial2005.htm

Zapata, Y. I. (Personal communication, March 28-29, 2008). Abordaje y tratamiento de poblaciones afectadas por la violencia. Coloquio Conflicto armado: memoria, trauma y subjetividad. Nueva Escuela Lacaniana de Medellín. 